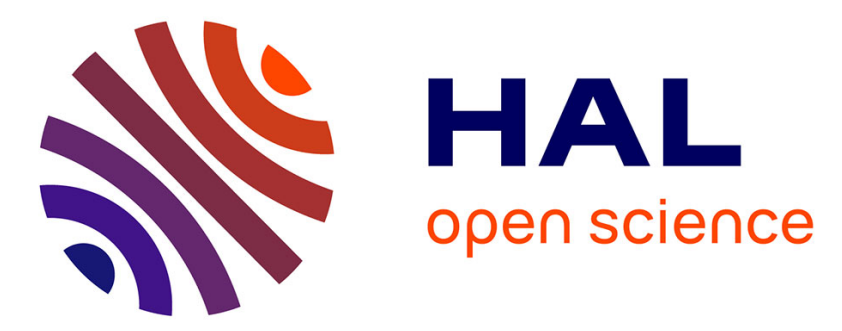

\title{
Self-fed whey in bacon pig feeding: Influence of the energy level and physical form of the supplementary feed
}

C. Fevrier, B. Lachance

\section{To cite this version:}

C. Fevrier, B. Lachance. Self-fed whey in bacon pig feeding: Influence of the energy level and physical form of the supplementary feed. Annales de zootechnie, 1988, 37 (3), pp.209-210. hal-00888672

\section{HAL Id: hal-00888672 \\ https://hal.science/hal-00888672}

Submitted on 1 Jan 1988

HAL is a multi-disciplinary open access archive for the deposit and dissemination of scientific research documents, whether they are published or not. The documents may come from teaching and research institutions in France or abroad, or from public or private research centers.
L'archive ouverte pluridisciplinaire HAL, est destinée au dépôt et à la diffusion de documents scientifiques de niveau recherche, publiés ou non, émanant des établissements d'enseignement et de recherche français ou étrangers, des laboratoires publics ou privés. 


\title{
Influence of the physical form of the feed on the performance of bacon pigs. 1. Comparison between dry meal, soup and pellets. 2. Technical and economical influence
}

\section{P. QUEMERE (1), J. CASTAING ${ }^{(2)}$, J.P. CHASTANET ${ }^{(3)}$, F. GROSJEAN ${ }^{(6)}$ P. LATIMIER ${ }^{(4)}$, J. SAULNIER ${ }^{(5)}$, F. WILLEQUET ${ }^{(1)}$}

(1) Société d'Etude Régionale sur l'Elevage du Porc, rue Pierre-Waguet, B.P. 313, 60026 Beauvais Cedex

(2) Association Générale des Producteurs de Maïs, 22, boulevard Tourasse, 64000 PAU

(3) Etablissement Départemental de l'Elevage d'Eure-et-Loir, 10, rue Dieudonné-Costes, 28024 Chartres

(4) Etablissement Départemental de l'Elevage des Côtes-du-Nord, B.P. 24, 22190 Plerin

(5) Institut Technique du Porc, La Motte-au-Vicomte, B.P. 3, 35650 Le Rheu

(6) Institut Technique des Céréales et Fourrages, 8, avenue du Président-Wilson, 75116 Paris

Four trials involving 486 pigs were made in restricted feeding conditions to compare a diet fed either as a dry meal, a soup (2.5-3 l per $\mathrm{kg}$ diet), or as pellets (dry pellets in trials 2 and 3).

During the growing period, pellets improved the daily mean gain in all trials compared to dry meal or soup : on an average the daily mean gain reached $763 \mathrm{~g} / \mathrm{d}$ with pellets versus 703 and $707 \mathrm{~g} / \mathrm{d}$ with the other two diets. In three trials out of four, weight gain was lower with soup than with dry meal. During the finishing period, the highest growth rates were obtained with pellets and the lowest with dry meal. On an average, the daily gain was $792 \mathrm{~g} / \mathrm{d}$ with pellets, $744 \mathrm{~g} / \mathrm{d}$ with soup and $703 \mathrm{~g} / \mathrm{d}$ with dry meal. On the whole growing-finishing period, pellets led to the best performance $(776 \mathrm{~g} / \mathrm{d})$, dry meal to the lowest $(703 \mathrm{~g} / \mathrm{d})$ and soup to intermediate performance $(723 \mathrm{~g} / \mathrm{d})$.

In three trials out of four, carcass yield was higher with pellets, but on the average of the 4 trials, results were not different with the three diets.

In the 4 trials, the muscle percentage of carcasses was lower with pellets $(50.9$ p. 100) than with dry flour (52.0 p. 100) and soup (52.5 p. 100).

These technical results were followed by an economic analysis.

\section{Self-fed whey in bacon pig feeding: Influence of the energy level and physical form of the supplementary feed}

\author{
C. FEVRIER (1), B. LACHANCE ${ }^{(2)}$
}

(1) INRA, Station de Recherches Porcines, Saint-Gilles, 35590 L'Hermitage

(2) Agriculture Canada, Station de Recherches, B.P. 90,

Lennoxville, Quebec J1M 1Z3, Canada

A total of 128 Large-White pigs were distributed into 8 groups and 4 replicates of 2 castrated males and 2 females kept together. The factorial design combined 2 levels $(2.5$ and $6.5 \mathrm{p} .100)$ of crude fibre (wheat bran), in diets pelleted or not and including whey or not. From a live weight of $26-100 \mathrm{~kg}$, pigs were fed the diet ad libitum, whereas whey reconstitued daily (6.5 p. 100 of DM) from powder was acidified by lactic acid bacteria ( $\mathrm{pH} \mathrm{4.6)}$ and fed at the trough for 4-6 hours a day. Water was available in the same trough the rest of the time.

Pigs fed the low-fibre diet ingested significantly $(\mathrm{p}<0.01)$ less dry matter $(2.09$ vs $2.27 \mathrm{~kg}$ ), less whey (12 vs 18.2 p. 100), had a higher daily mean gain (DMG) (811 vs $724 \mathrm{~g}$ ) and a better feed conversion ratio (CR) ( 2.6 vs 3.19$)$ than those fed the cellulose-rich diet. Pelleting of diets 
significantly $(\mathrm{p}<0.01)$ improved DMG (786 vs $751 \mathrm{~g})$ and $\mathrm{CR}(2.80$ vs 2.89$)$. Whey intake improved DMG (787 vs $750, p<0.01)$. Improvement of the gain was all the more marked as the feed was pelleted ( 821 vs $754 \mathrm{~g})$ and the whey intake was low (12.5 vs $17.7 \mathrm{p}$. 100), as compared to pigs fed the diet in the form of meal ( $752 \mathrm{vs} 748 \mathrm{~g}$ ) and water only. Increase in the dietary cellulose content led to a significant reduction $(p<0.01)$ in the carcass adiposity and to an increase in muscle quantity in relationship with a decreased growth rate. Feed pelleting and whey supplementation did not affect carcass quality, although an increased flare fat deposition was observed in pigs fed whey.

In a total digestibility trial, 24 pigs were distributed into 6 groups and 4 replicates according to a factorial design $3 \times 2$. Three levels $(2.5,4.5$ and $6.5 \mathrm{p} .100)$ of crude fibre (wheat bran) were combined to the absence or presence of whey at a level of $30 \mathrm{p} .100$ of dietary DM. The same combination was studied for ileal digestibility in six pigs fitted with an ileo-rectal anastomosis, using a latin square design. The apparent digestibility coefficients (aDC) of all dietary nutrients were significantly reduced $(p<0.01)$ by the increase in the cellulose content : by 4 points for energy for 1 p. 100 crude fibre, but the presence of 30 p. 100 whey also provoked an additional reduction by 4 points. However, significant interactions only occurred between these factors for cell-wall constituents. Digestibility of the lignin-cellulose fraction, and at a lesser extent that of hemicelluloses was lower in cellulose-poor diets than in the others. The difference between total and ileal aDC for each diet was generally positive, except for lipids. However, the magnitude of the difference varied according to the diets : from 4 points for energy with cellulose-poor diets with water up to 13 points for whey-rich diets.

\title{
Evaluation of wet brewers' yeast in diets for bacon pigs
}

\section{J. CHAUVEL ${ }^{(1)}$, R. GRANIER ${ }^{(2)}$}

(1) Institut Technique du Porc, Domaine de la Motte-au-Vicomte, B.P. 3, 35650 Le Rheu (2) Station Expérimentale Les Cabrières, 12200 Villefranche-de-Rouergue

Two trials were made to assess the performance of bacon pigs fed wet brewers' yeast. In both trials, the absence or the presence of yeast was tested. In the first trial, yeasts accounted for $\mathbf{9} \mathbf{p}$. 100 of DM in a diet including whey and 16 p. 100 in the second one. Each trial involved 160 animals, i.e. 80 animals per treatment. In both trials, the diet was given according to a progressive and continuous feeding scheme until a maximum level of $8,200 \mathrm{Kcal} \mathrm{DE}$ for castrated males and $9,300 \mathrm{Kcal}$ for females. A maximum of $1,7 \mathrm{l}$ of yeast was given in the first trial and 2,8 1 in the second one.

Incorporation of yeasts improved the fattening performance (growth rate and feed conversion ratio) by 6 p. 100 in the first trial and 8 p. 100 in the second one as well in females as in castrated males.

It was concluded that steam-killed wet brewers' yeast with a minimum dry matter content of $130 \mathrm{~g} / \mathrm{l}$ may supply 50 p. 100 of protein supplementation.

\section{Monosodium glutamate supplementation of pig starters}

\author{
F. GATEL ${ }^{(1)}$, G. BURON ${ }^{(1)}$, P. GUION ${ }^{(2)}$, J. FEKETE ${ }^{(1)}$
}

(1) Institut Technique des Céréales et Fourrages, 8, avenue du Président-Wilson, 75116 Paris

(2) Société ORSAN, 16, rue Ballu, 75009 Paris

In intensive management conditions, it is recommended to give starter feeds to piglets from the first days of age in order to improve post-weaning performance. Palatability of the starter feed is important to insure adequate consumption of the required nutrients. The monosodium glutamate 